\title{
Mombesara pada Penyambutan Tamu Suku Tolaki
}

\author{
${ }^{1}$ Ramlin, ${ }^{2}$ Nuryadin \\ ${ }^{1}$ Dosen Universitas Lakidende Unaaha \\ ${ }^{2}$ Dosen Universitas Lakidende Unaaha \\ Correspondence Email: spdramlin@gmail.com
}

\begin{abstract}
Abstrak. Mombesara merupakan salah satu tradisi lisan yang diturunkan dari generasi ke generasi yang harus dilestarikan. Kegiatan adat dan budaya ini biasa disebut pesta budaya yang merupakan miniatur dalam mencerminkan kehidupan sosial dan nilai-nilai tradisional yang luhur, sebagai gambaran tradisi dan budaya lokal. Bahasa yang digunakan di mombesara adalah: a) harus menggunakan bahasa daerah asli Tolaki. b) bentuk tuturan adat harus disesuaikan dengan konteks pelaksanaan adat. Terjadinya proses Mombesara penyambutan tamu karena adanya dialog antara Pabitara dan Tina Mbutobu kepada tamu yang baru hadir sebagai bentuk penghormatan dan penyambutan adat. Bahasa yang digunakan dengan santun di mombesara mengandung makna dan nilai yang perlu diketahui. Untuk mengetahui makna dan nilai yang terkandung dalam mombesara yang dituturkan oleh Pabitara dan Tina Mbutobu, diperlukan pengetahuan kebahasaan untuk menganalisis bahasa tersebut. . Strategi yang digunakan dalam penelitian ini adalah mencari data, ide dan konsep, serta memfokuskan pada keabsahan data sesuai dengan kenyataan di lapangan. Untuk memperoleh pemahaman yang mendalam tentang data tentang masalah dan topik yang dipelajari, yang terkait dengan penyambutan tamu.
\end{abstract}

Kata Kunci: Mombesara, Tradisi, Penyambutan Tamu

Abstract: Mombesara is one of the oral traditions passed down from generation to generation that must be preserved. These traditional and cultural activities are usually called cultural parties which are miniature in reflecting social life and noble traditional values, as an illustration of local traditions and culture.The languages used in mombesara are: a) must use the original Tolaki regional language. b) the form of customary speech must be adapted to the context of the implementation of the custom. The occurrence of the Mombesara process of welcoming guests was due to the dialogue between Pabitara and Tina Mbutobu to the newly present guests as a form of respect and traditional welcome. The language used politely in mombesara contains meanings and values that need to be known. To find out the meanings and values contained in mombesara spoken by Pabitara and Tina Mbutobu, linguistic knowledge is needed to analyze the language.This research method is a descriptive-qualitative method, namely explaining the meaning and value contained in the speech of mombesara welcoming guests. The strategy used in this research is to find data, ideas and concepts, and focus on the validity of the data according to the reality in the field. To obtain an in-depth understanding of the data about the problems and topics being studied, which are related to welcoming guests.

Keywords: Mombesara, Tradition, Welcome guests

\section{PENDAHULUAN}

Bangsa Indonesia terdiri dari beraneka ragam suku (etnis) yang mendiami seluruh pelosok tanah air dimana masing-masing suku tersebut memiliki budaya yang dapat membedakan cirri satu dengan yang lainya. Budaya yang dimaksud adalah budaya daerah yang dipandang sebagai suatu cara hidup dan dianut pada setiap kelompok masyarakat. Keanekaragaman budaya ini menimbulkan hasrat dan aspirasi akan terwujudnya kebudayaan yang menjadi milik bersama, dan kebudayaan bersama ini terlibat dalam proses dialog tanpa henti dengan keragaman kebudayaan lokal dan gejala globalisasi yang semakin deras. Karena itu, kebudayaan senantiasa mengalami proses perkembangan atau pertumbuhan seirama dengan perputaran waktu. 
Salah satu tradisi yang dihasilkan dalam proses kreativitas suatu masyarakat adalah tradisi lisan. Tradisi lisan yang biasa disebut juga tradisi lokal padadasarnya merupakan produk kreativitas yang mendalam terhadap segala aspirasi, cita-cita, keinginan, dan ide bagi masyarakat lama yang bercorak tradisional dan disampaikan secara lisan atau oral. Tradisi lisan sangat erat hubungannya dengan kesusastraan daerah yang mengandung berbagai hal yang menyangkut komunitas hidup pemiliknya yang disampaikan melalui tuturan.

Tradisi lisan adalah kekayaan budaya bangsa dan merupakan salah satu ekspresi kebudayaan daerah yang berharga, menyimpan nilai-nilai budaya dari masyarakat tradisional dan kelak menjadi akar budaya bagi masyarakat baru untuk menciptakan budaya baru dalam masyarakat modern. Karena tradisi lisan merupakan penciptaan yang ada dalam masyarakat, berarti mendorong kita untuk mengenal identitas dalam masyarakat tersebut. Identitas yang dimaksud adalah wujud atau bentuk-bentuk tradisi lisan baik secara intern maupun ekstern. Oleh karena itu tradisi lisan harus dihidupkan dan dipertahankan kelestariannya sebagai salah satu aset yang berguna dan bermakna sebagai modal kultur, sebaliknya sebagai salah satu aset budaya dan tidak akan berguna dan bermakna kalau masyarakatnya sendiri tidak mengetahui arti dari segi Semantik, karena untuk menghidupkan dan melestarikan suatu budaya apabila pemiliknya memahami artinya atau maknanya, hal ini dapat diketahui kalau dikaji melalui bahasa yang digunakan baik bahasa verbal maupun bahasa non verbal.

Salah satu tradisi lisan yang sangat populer dalam kehidupan masyarakat suku-suku diwilayah Sulawesi Tenggara khususnya masyarakat Tolaki adalah mombesara penyambutan tamu. Tradisi ini merupakan salah satu tradisi lisan yang diwariskan dari generasi ke generasi yang harus dilestarikan. Kegiatan-kegiatan tradisi dan budaya ini biasanya disebut pesta budaya yang merupakan miniature dalam mencerminkan kehidupan sosial serta nilai-nilai ketradisian yang luhur, sebagai gambaran tradisi dan budaya setempat.

Bahasa yang digunakan dalam mombesara yakni: a) harus memakai bahasa daerah tolaki yang asli. b) bentuk tuturan adatnya harus disesuaikan dengan konteks pelaksanaan adat tersebut. Terjadinya proses Mombesara penyambutan tamu disebabkan adanya dialog Pabitara dan tinambutobu kepada tamu yang baru hadir sebagai bentuk penghormatan dan penyambutan secara adat. Bahasa yang digunakan dengan santun dalam mombesara mengandung makna dandan nilai yang perlu diketahui. Untuk mengetahui makna dan nilai yang terkandung dalam mombesara yang dirtuturkan oleh Pabitara dan Tina Mbutobu dibutuhkan pengatahuan kebahasan untuk menganalisis bahasa tersebut.

Kajian tradisi lisan berbeda dengan akademik sejarah lisan, yang merupakan rekaman ingatan pribadi dan sejarah oleh mereka yang mengalami era sejarah atau kejadian tertentu. Kajian tradisi lisanjuga berbeda dengan kajian kelisanan (orality) yang dapat dikatakan sebagai pemikiran dan gambaran lisan dalam masyarakat dimana teknologi kesusastraan (utamanya tulisan dan cetakan) tidak meluas di kalangan penduduknya.

Tradisi lisan merupakan salah satu bentuk ekspresi kebudayaan daerah yang jumlahnya beratus-ratus di seluruh Indonesia. Kemampuan tradisi lisan untuk melingkupi segala sendi kehidupan manusia, membuktikan bahwa nenek moyang kita dimasa lampau telah mengenal ajaran kehidupan yang terkandung dalam tradisi lisan.

Vansina (dalam Hamidy, 2008:25) member batasan tradisi lisan (oral tradition) sebagai oral testimony transmitted verbally, from onegeneration to the next one or more. Dalam tradisi lisan, tidak termasuk kesaksian mata yang merupakandata lisan. Juga disini tidak termasuk perasaan masyarakat atau gosip meskipun lisan tetapi tidak ditularkan dari satu generasi kegenerasi lain. Tradisi lisan dengan demikian terbatas di dalam kebudayaan lisan dari masyarakat yang belum mengenal tulisan. Sama seperti dokuman dalam masyarakat yang sudah mengenal tulisan, tradisi lisan merupakan sumber sejarah yang merekam masa lampau. Namun kesejarahan tradisi lisan barulah sebagaian dari isi tradisi lisan itu sendiri, karena banyaknya peristiwa keseharian, niali-nilai moral, keagamaan, adat-istiadat, cerita-cerita khayali, peribahasa, nyanyian, dan mantra yang terkandung dalam tradisi lisan lisan menjadikannya sumber penulisan bagi antropolog, sejarawan, penulis naskah drama, dan pekerja seni lainnya. 
Selanjutnya, teori yang berkaitan dengan tuturan dalam penelitian ini mengacu pada pendapat Faruk(2014:45) bahwa tingkat atau derajat intelektualitas tidaklah sama, adat tuturan dengan tanda intelektualitasnya tinggi, rendah, dan bahkan kosong sama sekali. Suatu tuturan disebut juga monologis, apabila di dalamnya tidak ditemukan sama sekali suara lain, selain itu disamping suara penutur,tidak dapat pula ditemukan persoalan-persoalan pengombinasian suara-suara.

\section{LANDASAN TEORI}

Tari Mondotambe atau tari penyambutan adalah merupakan tarian khas suku Tolaki yang kerap ditampilkan pada saat pelaksanaan acara yang berskala besar dan untuk penyambutan tamu besar dan istimewa. Tarian dilakoni 12 orang penari perempuan muda dan 2 penari pria sebagai pengawal. Penari perempuannya memakai busana motif tabere (hiasan), sarung tenun Tolaki dan aksesoris seperti ngaluh (ikat kepala) serta kalung. Dalam tarian yang berdurasi 5 sampai 10 menit ini beberapa penari perempuan membawa bosara atau bokor dari rotan, sedangkan 2 penari pria memegang senjata tradisioal. Dalam penelitian ini, eksistensi tari Mondotambe juga dianalisis menggunakan teori sejarah.Para ahli sejarah sepakat bahwa untuk membagi peranan dan kedudukan sejarah dapat dibagi atas tiga, yakni: (1) Sejarah sebagai peristiwa; (2) Sejarah sebagai cerita, dan; (3) Sejarah sebagai ilmu (Ismaun, 1993: 277). Pertama, Sejarah sebagai peristiwa; adalah sesuatu yang terjadi pada masyarakat manusia di masa lampau. Pengertian pada "masyarakat manusia"dan "masa lampau" sesuatu yang penting dalam definisi sejarah.

Sejarah sebagai peristiwa sering juga disebut sejarah sebagai kenyataan dan sejarah serba obyektif (Ismaun, 1993: 279). "Artinya peristiwa-peristiwa tersebut benar-benar terjadi yang didukung oleh evidensievidensi yang menguatkan baik berupa saksi mata (witness) yang dijadikan sumber-sumber sejarah (historical sources), peninggalan-peninggalan dan catatan-catatan" (Lucey, 1984: 27). Selain itu dapat pula peristiwa itu diketahui dari sumber-sumber-sumber yang bersifat lisan yang disampaikan dari mulut ke mulut.

Menurut Sjamsuddin (1996: 78), bahwa ada dua macam untuk sumber lisan tersebut. Pertama, sejarah lisan (oral history), ingatan lisan (oral reminiscence) yaitu ingatan tangan pertama yang dituturkan secara lisan oleh orang-orang yang diwawancarai oleh sejarawan. Kedua, tradis lisan (oral tradition) yaitu narasi dan deskripsi dari orang-orang dan peristiwa-peristiwa pada masa lalu yang disampaikan dari mulut ke mulut selama beberapa generasi. Apapun bentuknya, peristiwa sejarah, baru diketahui apabila ada sumber yang sampai kepada sejarawan dan digunakan untuk menyusun peristiwa berdasarkan sumber. Oleh karena suatu cerita sejarah sangat tergantung selain oleh kemahiran sejarawan itu sendiri juga kelengkapan sumber yang tersedia.

\section{METODE PENELITIAN}

Penelitian ini termasuk jenis penelitian lapangan karena peneliti secara langsung kelapangan untuk mengumpulkan data. Metode yang digunakan ialah metode deskriptif-kualitatif, karena tujuan penelitian ini adalah untuk menjelaskan makna dan nilai yang terkandung dalam tuturan mombesara penyambutan tamu. Disamping itu, karena fenomena yang menjadi sasaran penelitian dideskripsikan sebagaimana adanya tanpa disertai perhitungan statistik, maka metode dalam penelitian inipun menggunakan metode kualitatif. Penggunaan metode kualitatif tersebut dilakukan karena data yang dihasilkan adalah data deskriptif berupa tuturan-tuturan lisan dari orang yang mengetahui tuturan mombesara penyambutan tamu.

Teknik Analisis Data Setelah data terkumpul selanjutnya dilakukan analisis dengan menggunakan analisis deskripsi. Analisis deskripsi digunakan untuk menganalisis data yang sudah terkumpul dengan cara mendeskripsikan atau menggambarkan makna dan nilai yang terkandung dalam tuturan mombesara penyambutan tamu.

\section{HASIL DAN PEMBAHASAN \\ Gambaran Umum Mombesara}

Mombesara adalah suatu proses penyampaian perangkat adat dalam upacara adat perkawinan suku tolaki, proses mombesara yang dilaksanakan oleh pembicara dari pihak laki-laki yang disebut tolea dan 
pembicara dari pihak perempuan disebut pabitara. Dalam tahap Mombesara ini terdapat empat tingkatan yaitu tahap morake-rakepi, monduutudu, mowawo niwule dan mowindahako yang dilibatkan pembicara dari pihak laki-laki (tolea) dan pembicara dari pihak perempuan (pabitara). Penutur Tolea merupakan penutur kunci atau inti dalam setiap pelaksanaan upacara adat Mombesara yang merupakan juru bicara dari pihak laki-laki, sedangkan penutur pabitara merupakan penutur pelengkap yang merupakan pemberi jawaban atas pertanyaan adat berupa tuturan Mombesara dari piahak perempuan dalam setiap pelaksanaan upacara adat perkawinan etnis tolaki.

Tuturan Mombesara pada setiap pelaksanaan adat perkawinan etnis Tolaki, bentuk tuturannya beragam, unik dan berbeda bentuk tuturannya, yang dituturkan oleh tolea dan pabitara. Bahasa adat yang dipergunakan dalam tuturan adat mombesara yakni:

1. Ragam bahasa tolaki standar (kuno)

2. Menggunakan Bahasa Daerah Tolaki yang asli dan benar

3. tuturannya harus sesuai dengan konteks tahap perkawinan

Pelaksanaan upacara adat perkawinan (mowindahako) pada etnis tolaki dimulai dari beberapa tahap, tahapan yang dimaksud adalah:

1. Tahap Morake-rakepi (mengikuti dan meninjau calon istri)

2. Tahap Monduutudu (tahap pelamaran jejaka)

3. Tahap Mowawo niwule (tahap pelamaran sesungguhnya)

4. Tahap mowindahako (tahap upacara perkawinan/pernikahan)

Dalam prosesi adat mombesara ini terdapat aturan lain didalamnya, yaitu syarat isi adat yang harus dipenuhi oleh pihak laki-laki, diantaranya adalah Puu'uno Osara (pohonnya Adat) meliputi :

1. Tawa-tawa sara (gong adat)

2. Kiniku sara (kerbau adat) dan eno sara (kalung adat)

3. Tawano osara (daun-daunnya) meliputi: kaci, sarung, periuk, kain penggendong bayi dan kelengkapan adat lainnya.

\section{Hakikat Mombesara Pada Masyarakat Tolaki}

Mombesara adalah sebagai salah satu Budaya Tolaki dalam melaksanakan proses upacara perkawinan suku tolaki. Dalam hal ini mombesara dilibatkan dua pembicara yaitu tolea dan pabitara. Mombesara mempunyai banyak tuturan yang berbeda, karena dalam pelaksanaan perkawinan suku tolaki terdapat empat tingkatan yaitu tahap morake-rakepi, monduutudu, mowawo niwule dan mowindahako. Bila memandang tuturan mombesara sebagai sesuatu yang bermakna, maka seseorang tersebut akan mampu menghayati kehidupan budaya.

Tuturan mombesara merupakan suatu aturan yang mengatur budaya antara pihak perempuan dan pihak laki-laki dan mengatur budaya manusia dan sesamanya yang bersifat gagasan dan kebenaran.

Upacara pernikahan suku tolaki merupakan salah satu upacara tradisional yang dilakukan secara turun - temurun dan berlaku secara umum pada suku tolaki. Artinya upacara tradisional ini dilaksanakan tanpa mengenal adanya strata sosial atau tidak adanya perbedaan miskin dan kaya. Dapat diketahui bahwa yang terkandung dalam tuturan mombesara bersifat kultural, artinya pendukung kegiatan ini cenderung beranggapan bahwa makna-makna bahasa itu akan berlaku disetiap lini kehidupan suku tolaki, jadi anggapan sikap kolektif yang menjadi ciri khas setiap kelompok budaya masyarakat penganutnya,

\section{Makna Tuturan Mombesara}

Untuk mengkaji mengenai makna dalam tuturan mombesara yang dituturkan oleh Tolea dan Pabitara, maka digunakan teori semantik yang berhubungan dengan makna. Dalam teori tersebut dikemukakan oleh seorang ahli yakni, Djajasudarma, (1999: 75), makna adalah pengertian atau konsep yang dimiliki atau terdapat pada sebuah tanda-linguistik.

\section{Makna Tuturan Mombesara Pada Tahap Morake - Rakepi.}

Arti dari tuturan Mombesara pada tahap Morake - rakepi sebagai berikut: 
Yang kami hormati bapaknya tie, dan

Yang kami hormati ibunya tie

Kami memang sengaja,

Datang melawat saat ini

Sebagai utusan bapaknya bio dan ibunya bio

Mereka ada mememdam suatu rasa dan memiliki suatu keinginan

Untuk datang berbasa-basi bermaksud menabur benih cinta kasih

Terhadap keluarga besar bapak dan ibu

Jika mungkin lawatan kami beralamat baik

Hingga gayung dapat bersambut

Utusan mereka akan segera manapak kembali

Sebagai alas kata basa-basi kami,

Bersama ini kami Persembahkan adat kami satu mata

Pada paragraf pertama, bentuk tuturan Mombesara mempunyai makna yang signifikan bahwa, memberikan sebuah penghormatan atau penghargaan kepada orang lain adalah tabiat yang terpuji yang berlandaskan suatu bentuk prilaku yang dimiliki oleh setiap insan. Dalam kehidupan sehari - hari sangatlah dibutuhkan prilaku yang sifatnya menghargai sesama umat manusia.

Pada paragraf pertama Mombesara pada tahap morake - rakepi terdapat kata Inggomiu kata tersebut dapat dimaknai dengan kata Yang Kami Hormati. Makna yang terkandung dalam frase tersebut mempunyai makna yang mengajarkan kita untuk saling menghargai sesama umat manusia, utamanya pada kehidupan sehari - hari dalam bermasyarakat dan lebih spesifik lagi pada acara - acara adat. Dan tuturan tersebut kata Inggomiu atau Yang Kami Hormati adalah kata - kata pembuka pada saat memulai tuturan adat Mombesara. Kata Inggomiu adalah kata - kata penghargaan atau penghormatan kepada seseorang baik itu Pejabat, Pemerintah, Ketua Adat maupun petinggi adat.

Berikut ini adalah tuturan adat mombesara yang menggunakan bahasa indonesia seperti:

Kami memang sengaja

Datang melawat saat ini sebagai

Utusan dari bapaknya i bio dan ibunya i bio

Makna yang terkandung pada bentuk tuturan ini mengandung makna sebagai kata yang mengandung nilai sebagai suatu bentuk tuturan yang menjunjung tinggi nilai - nilai budaya yang terkandung dalam adat istiadat utamanya pada tahap Morake - rakepi. Sehingga generasi penerus masih akan tetap mempertahankan dan melestrikan nilai - nilai budaya tersebut.

Makna tuturan Mombesara yang dituturkan oleh tolea di atas mengacu pada hal yang mempunyai maksud melakukan pelamaran kepada pihak perempuan, tetapi maksud dari tujuan kedatangan pihak keluarga laki - laki tersebut tidak diutarakan secara langsung tetapi dengan kata - kata yang mempunyai makna kata pada Umololaikakomiu - Sumindawakomiu (Datang Melawat Saat Ini) pada tuturan ini pihak laki-laki datang kerumah perempuan tersebut untuk menjalin suatu tali silahturahmi walaupun mempunyai maksud dan tujuan yang lain atau yang khusus.

Dalam hal tuturan adat ini dapatlah kita cerna dan perlu untuk dilestarikan dan dipertahankan, karena manusia diciptakan untuk saling berpasang - pasangan dan pada tuturan ini mengajarkan kita untuk tidak melanggar hal - hal yang tidak diinginkan, contohnya berpacaran dan melakukan perbuatan - perbuatan yang dilanggar oleh agama sebelum ada ikatan yang resmi dalam agama.

Makna yang terkandung pada paragraf ketiga pada tuturan adat mombesara seperti berikut:

Mereka ada mememdam suatu rasa dan memiliki suatu keinginan

Untuk datang berbasa-basi bermaksud menabur benih cinta kasih

Terhadap keluarga besar bapak dan ibu

Makna yang terkandung pada tuturan ini adalah, adanya keinginan pihak laki-laki untuk melamar anak gadis tersebut. Tetapi pada tuturan ini utusan laki-laki di ibaratkan hanya datang untuk berbasa - basi atau berjalan - jalan kerumah perempuan tersebut. Akan tetapi pada tahap ini maksud menabur benih untuk memperkenalkan diri bahwa ada maksud terhadap kelurga besar perempuan tersebut. 
Makna yang terkandung dalam tuturan ini Untuk datang berbasa-basi bermaksud menabur benih, termasuk dalam bahasa kiasan majas sinekdoke pars pro toto atau majas pertautan yang menyebutkan nama bagian sebagai penganti nama keseluruhannya. (Suharma, 129: 2010)

Makna paragraf berikutnya pada tuturan adat mombesara sebagai berikut:

Jika mungkin lawatan kami beralamat baik

Hingga gayung dapat bersambut

Utusan mereka akan segera menapak kembali

Makna dari tuturan Mombesara tersebut adalah, jika orang tua dari anak gadis tersebut menerima lamaran dari pihak keluarga laki - laki serta anak gadis tersebut setuju dan mau menerima lamaran tersebut yang di ajukan dari pihak laki-laki, maka akan ada dari pihak keluarga perempuan berkunjung kerumah pihak keluarga laki-laki, secara spesifik maksud dari tuturan tersebut adalah pihak laki-laki menaruh sebuah harapan kepada pihak keluarga perempuan, bahwa jika pihak keluarga perempuan menyetujui atau merestui lawatan tersebut maka keluarga laki-laki akan melanjutkan ketahap berikutnya, dan apabila keluarga pihak perempuan tidak menyetujui atau tidak merestui lawatan tersebut maka keluarga dari pihak perempuan akan mengembalikan lawatan tersebut.Sedangkan makna tuturan adat Mombesara pada kalimat terakhir adalah :

\section{Sebagai alas kata basa basi kami \\ Bersama ini kami persembahkan adat satu mata}

Makna yang terkandung dalam tuturan adat Mombesara pada kalimat terakhir ini yaitu, untuk memperkuat kesungguhan dari pihak laki-laki tersebut yang bukan hanya argumen belaka yang tidak bermamfaat atau hanya sebuah basa-bai saja. Maka pihak dari keluarga laki-laki mempersembahkan atau meletakan adat satu mata. Adat satu mata yang dipersembahkan dari keluarga pihak laki-laki merupakan tanda bahwa mereka ingin mendapatkan jawaban atas lawatan ini, apakah dari pihak perempuan setuju atau tidak. Biasanya adat satu mata ini berbentuk sarung adat, dan apabila lawatan dari pihak laki-laki diterima sarung itu tidak akan kembali, jika sebaliknya atau lawatan tidak diterima sarung itu akan dikembalikan oleh pihak perempuan.

Pada tuturan tersebut terdapat bahasa kiasan atau majas Sinekdoke totem pro parte atau majas yang menyebutkan nama kesuluruhan sebagai penganti nama bagiannya.

Setelah itu balasan dari kata-kata pabitara makna yang dituturkan oleh Pabitara atau pihak dari perempuan sangatlah jelas, berikut penuturannya:

\section{Kembalilah dahulu sambil menanti petunjuk lebih lanjut} Kami masih perlu berfirasat dan menyimpulkn pendapat

Makna dari tuturan tersebut Pihak laki-laki disuruh kembali pulang kerumah karena pihak keluarga perempuan masih akan berfirasat dan mempertimbangkan terima apa tidaknya lawatan tersebut.Tuturan pada paragraf berikutnya dalam tuturan Mombesara sebagai berikut:

\section{Jika mungkin gayung akan bersambut utusan kami akan menapak Andai gayung tak akan bersambut Alas kata pasti akan kembali}

Makna dari tuturan tersebut yaitu jika orang tua dari pihak perempuan menerima lawatan tersebut, serta anak gadis tersebut setuju dan mau menerima lamaran yang diajukan dari pihak keluarga laki-laki serta anak gadis tersebut setuju dan mau menerima lamaran yang diajukan dari keluarga pihak laki-laki maka pasti ada dari pihak keluarga perempuan berkunjung kerumah keluarga pihak keluarga laki-laki. Secara spesifik makna dari tuturan tersebut yaitu apabila keluarga pihak perempuan lawatan tersebut tidak diterima maka keluarga dari pihak perempuan akan kerumah pihak laki-laki mengembalikan adat satu mata (Sarung). 
Pada tuturan tersebut Andai gayung tak akan bersambut, alas kata pasti akan kembali. Mempunyai bahasa kiasan atau majas Litotes, pernyataan yang memperkecil atau melemahkan sesuatu atau dengan menyatakan kelebihannya

\section{SIMPULAN}

Berdasarkan hasil penelitian yang telah dilakukan dapat disimpulkan beberapa halt ersebut adalah dalam tuturan mombesara pada setiap tuturan adatnya mempunyai fungsy dan makna yang berbeda seperti berikut ini; 1) Tahap morake-rakepi, makna dan fungsy tuturan mombesara yang dituturkan oleh Tolea dan Pabitara sangat berbeda dengan tahapan selanjutnya, 2) Tahap mondutudu terdiri dari berbagai macammakna dan fungsy penuturanya yang sangat berbeda-beda seperti pada bantuk tuturan yang pertama; a) tuturan permohonan izin untuk memulai acara. Adanya kesadaran untuk mempertahankan budaya lokal secara spesifik budaya mombesara pada etnis Tolaki yang telah diwariskan dari generasi-generasi pendahulu kita, agar tidak lenyap terhadap arus globalisasi yang sudah masuk dalam kebudayaan kita sehingga perlahan-lahan budaya Mombesara ini di kalangan etnis Tolaki akan hilang dan digantikan dengan budayabudaya yang lain. Perlunya memperkenalkan budaya mombesara ini kepada generasi-generasi sekarang baik suku Tolaki maupun suku-suku lain, agar mengetahui lebih inklusif lagi tentang fungsy dan makna yang terkandung dalam tuturan Mombesara tersebut.

\section{DAFTAR PUSTAKA}

Bertens, K, 2007. Etika. Gramedia Pustaka Utama. Jakarta.

Chaer, Abdul. 2009. Pengantar Semantik Bahasa Indonesia. Jakarta: Rineka Cipta. Chaer, Abdul. 2007. Linguistik Umum. Jakarta: Rineka Cipta.

Djajasudarma,T.Fatimah. 2008. Linguistik-Semantik Dialektologdalam ParadigmaMasa PramodernModern-Pascamodern. Bandung:Universitas Padjajaran.

Faruk.2009. Pengantar SosiologiSastra. Yogyakarta: PustakaPelajar.

Hamidy, UU. 2008.Nilai Suatu Kajian Awal. Pekanbaru: UIR Press.

Kridalaksana,Harimurti,2008.Fungsi dan Sikap Bahasa,Ende: NusaIndah

Kamus Linguistik, 2008 .Jakarta: PT. GramediaPustakaUtama.

Koentjaraningrat. 2009. Kebudayaan, Mentalitas, dan Pembangunan. Jakarta:Gramedia 